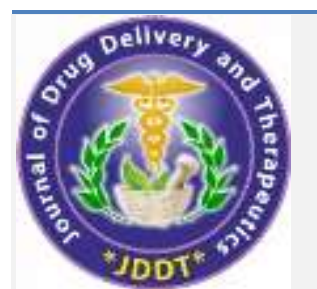

\section{Journal of Drug Delivery and Therapeutics}

Open Access to Pharmaceutical and Medical Research

Copyright (C) 2021 The Author(s): This is an open-access article distributed under the terms of the CC BY-NC 4.0 which permits unrestricted use, distribution, and reproduction in any medium for non-commercial use provided the original author and source are credited

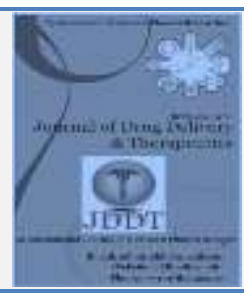

Research Article

Open Access Full Text Article

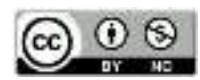

\title{
Phytochemical analysis of different extracts of Pinda concanensis and Heracelum grande
}

\author{
Sucheta Bidve ${ }^{1}$ and Sanjay Auti2* \\ ${ }^{1}$ KRT arts, BH Commerce and AM Science College, Nashik-422003 (MS), India \\ ${ }^{2}$ HPT Arts and RYK Science, College, Nashik-422005 (MS), India
}

\section{Article Info:}

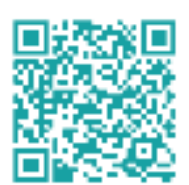

Article History:

Received 09 October 2021

Reviewed 01 December 2021

Accepted 06 December 2021

Published 15 December 2021

\section{Cite this article as:}

Bidve S, Auti S, Phytochemical analysis of different extracts of Pinda concanensis and Heracelum grande, Journal of Drug Delivery and Therapeutics. 2021; 11(6-S):100-103

DOI: http://dx.doi.org/10.22270/jddt.v11i6-S.5146

*Address for Correspondence:

Sanjay Auti, HPT Arts and RYK Science, College, Nashik-422005 (MS), India

\section{Abstract}

Aromatic plants are a reservoir of secondary metabolites that are responsible for the plants' medicinal efficacy and a major source of aromatic compounds and essential oils. Now a day, there is a renewed interest in the plant kingdom in the search for novel bioactive and fragrance compounds as demands for herbal products are increasing enormously. In the present study two endemic plants, Pinda concanensis and Heracelum grande from Western Ghats were analyzed for secondary metabolites by using different plant parts (roots, leaves, and seeds) and by using range of solvent from polar to non-polar. Glycosides, terpenoids, tannins, flavonoids, saponins, steroids, and alkaloids were found in methanolic extracts of Pinda concanensis root, leaf, and seeds and methanolic extracts of seeds of Heracelum grande. While extracts of chloroform and petroleum ether exhibits presence of some of them. Obtained results show the importance of both the plants as an important source of biologically active molecules for pharmaceuticals and cosmetic industries.

Keywords: Phytochemical screening, secondary metabolites, biologically active compounds.

\section{INTRODUCTION}

From ancient time plants being an integral part of life in many local communities for food, fodder, medicine and an important resource for health care. Multidisciplinary approach and biocompatibility of plant based pharmaceuticals have great importance in recent era 1,2 . More than $80 \%$ population of the world depends on medicinal plant species for their daily health care routines. Now a days pharmaceutical industries focusing to formulate plant based medicines. Near about $14-28 \%$ of higher plants species having applications in medicinal science and reported with more than $74 \%$ of bioactive compounds as elaborated in ethanobotany ${ }^{3}$. Therefore it is essential to develop new and sensitive techniques to identify biologically active compounds and technique to isolate, purify and characterize compound. The proposed study has been focused on phytochemical profiling of different extracts of Pinda concanensis and Heracelum grande belongs to family Apiaceae.

Family Apiaceae is one of the most important in flowering plants with more than 300 genera and 3000 species 4 Apiaceae is important family of medicinal plants, as it consists of variety of biologically active compounds with diverse mode of actions. The members of family Apiaceae shows presences of aromatic compounds, essential oils, fatty acids, organic acids, flavonoids, coumarins, terpenes, aliphatic compounds, polyenes, podophyllotoxins etc ${ }^{5,6,7}$. In traditional medicines family Apiaceae widespread and now a days several investigations explored their health benefits as antioxidants, antimicrobial, digestive, antiplasmodic, estrogenic, anti-inflammatory etc.

Pinda concanensis and Heracelum grande are endemic to Northern Western Ghats of Maharashtra. Both plants are wild relative of economically important members of family like coriander. The plant parts are consumed by tribal people as vegetables and seeds used in spices and used in folk medicines.

Seeds of Pinda concanensis used as supplementary to enhance fragrances of spices and food material and root were eaten raw by trial people as source of energy.

Ethnobotanically plant parts of Heracleum grande are used as antipyretic, analgesic, diaphoretic, antiseptic, carminative, digestive for rheumatic disease, lumbago, gastralgia, and injuries from falls, fractures, contusions and strains etc. The leaves of plant used as vegetable, seeds were used additionally in spices to enhance flavor while young stem and leaves were used for pickle preparation etc. 
As both plants having characteristic aroma of family so that they can be used a potential candidate for phytochemical investigations and could be source of novel compounds which can be used in pharmaceutical and cosmetic industries.

\section{MATERIALS AND METHODS:}

Collection of plant material:

Pinda concanensis (Dalzell) P.K.Mukh \& Constance and Heracelum grande (Dalzell \& A.Gibson) Mukhop was collected from Northen-western Ghats lays Nashik district, Maharashtra during August to October 2019 and 2020.

Pinda concanensis is Annual herb- grows upto 1-2 feet in high with Tuberous roots and Compound Leaves. Flowers small, white, fragrant flowers, in Umbel inflorescence.

While Heracelum grande is tall perennial herb with glabrous stem with tuberous roots and trifoliate compound leaves. Flowers are Small, yellow, fragrant flowers, in umbel inflorescence, Plant material cleaned and dried in shade at room temperature. The dried material finely powdered and used for extraction.

\section{Methods of Extraction:}

$1 \mathrm{gm}$ of powdered plant material of root, leaves and seeds were extracted with $10 \mathrm{ml}$ of different solvents (Petroleum ether, chloroform and methanol). Plant material soaked in different solvents and sonicated by using ultrasonic bath at $33 \mathrm{KHz}$ at $40^{\circ} \mathrm{C}$ for $40 \mathrm{~min}$. and allowed to stand for at least $24 \mathrm{hrs}{ }^{8}$. Then extracts were filtered, concentrated and used for phytochemical analysis.

\section{Phytochemical Screening:}

The commonly known phytochemical from plants are cardiac glycosides, terpenoids, steroids, tannin, flavonoids and alkaloids. The following qualitative tests were performed to explore phytochemical profile of both plants.

\section{Test for Cardiac Glycosides}

$0.50 \mathrm{ml}$ of each extract was treated with $0.2 \mathrm{ml}$ glacial acetic acid then 1 drop of $3.55 \%$ ferric chloride $\left(\mathrm{FeCl}_{3}\right)$ was added to the solution. This was layered with $1 \mathrm{ml}$ of concentrated
$\mathrm{H}_{2} \mathrm{SO}_{4}$. A reddish brown ring was occurred at the interface indicates the presence of cardiac glycosides.

\section{Test for Terpenoids}

$0.5 \mathrm{ml}$ of plant extract was added to the test tube $2 \mathrm{ml}$ of chloroform was mixed to the solution. $3 \mathrm{ml}$ of concentrated $\mathrm{H}_{2} \mathrm{SO}_{4}$ was added carefully from the wall of the test tube, to from a lower layer. Occurrence of reddish-brown color at the interface indicated the presence of terpenoids.

\section{Test for Steroid}

$0.5 \mathrm{ml}$ of plant extract was dissolved in $3 \mathrm{ml}$ of chloroform. The solution was filtered, $2 \mathrm{ml}$ of concentrated $\mathrm{H}_{2} \mathrm{SO}_{4}$ was added to from a lower layer. A reddish- brown color ring at the interface the presence of steroid.

\section{Test for Saponin}

$0.5 \mathrm{ml}$ of extract was taken in the test tube, and $5 \mathrm{ml}$ of distilled water was added to it. The solution was vigorously shaken and stable persistent froth was observed for the presence of saponin.

\section{Test for Tannin}

$0.5 \mathrm{ml}$ of extract and $5 \mathrm{ml}$ of distilled water was taken in test tube then it was boiled then filtered. Few drops of concentrated $\mathrm{H}_{2} \mathrm{SO}_{4}$ and $1 \% \mathrm{FeCl}_{3}$ were added to the filtrate. Deep green, brownish green or blue black coloration was indicated the presence of tannin.

\section{Test for Flavonoid}

$0.5 \mathrm{ml}$ of extract and $5 \mathrm{ml}$ of distilled water was added to test tube then it was filtered. $5 \mathrm{ml}$ of diluted ammonia solution was added to the filtrate then concentrated $\mathrm{H}_{2} \mathrm{SO}_{4}$ was added. A yellow coloration indicated the presence of flavonoid. The yellow color disappeared on standing.

\section{Test For Alkaloid}

$0.5 \mathrm{ml}$ of extract was dissolved in $2 \mathrm{ml}$ of methanol. Few drops of $1 \%$ HCL added to it. Then the mixture was heated, kept in steam and after cooling. Then the mixture was treated with few drops of Wagner's reagent. The sample was observed for turbidity or precipitation.

Observation Table 1: Phytochemical screening of Pinda concanensis

\begin{tabular}{|l|l|l|l|l|l|l|l|l|l|l|}
\hline \multirow{2}{*}{$\begin{array}{l}\text { Sr. } \\
\text { No. }\end{array}$} & Phytocompound & \multicolumn{4}{l|}{ Root extracts } & \multicolumn{2}{l|}{ Leafs extracts } & \multicolumn{2}{l|}{ Seed extracts } \\
\cline { 3 - 12 } & & P.E. & Chl. & Met. & P.E. & Chl. & Met. & P.E. & Chl. & Met. \\
\hline $\mathbf{1}$ & Glycosides & - & - & + & - & + & + & + & + & + \\
\hline $\mathbf{2}$ & Terpenoids & + & + & + & + & + & + & + & + & + \\
\hline $\mathbf{3}$ & Steroids & - & + & + & - & + & + & + & + & + \\
\hline $\mathbf{4}$ & Saponin & - & - & + & - & - & + & - & + & + \\
\hline $\mathbf{5}$ & Tannin & - & + & + & - & + & - & + & + & + \\
\hline $\mathbf{6}$ & Flavonoid & - & - & + & - & - & + & - & - & + \\
\hline $\mathbf{7}$ & Alkaloids & - & - & + & - & - & + & - & - & + \\
\hline
\end{tabular}


Observation Table 2: Phytochemical screening of Heracelum grande

\begin{tabular}{|l|l|l|l|l|l|l|l|l|l|l|l|}
\hline \multirow{2}{*}{$\begin{array}{l}\text { Sr. } \\
\text { No. }\end{array}$} & Phytocompound & \multicolumn{4}{l}{ Root extracts } & \multicolumn{2}{l|}{ Leafs extracts } & \multicolumn{2}{l|}{ Seed extracts } \\
\cline { 3 - 13 } & & P.E. & Chl. & Met. & P.E. & Chl. & Met. & P.E. & Chl. & Met. \\
\hline $\mathbf{1}$ & Glycosides & + & + & + & + & + & + & + & + & + \\
\hline $\mathbf{2}$ & Terpenoids & + & + & - & + & - & - & + & & + & + \\
\hline $\mathbf{3}$ & Steroids & - & - & + & - & + & + & - & & + & + \\
\hline $\mathbf{4}$ & Saponin & + & + & - & + & - & - & + & + & + \\
\hline $\mathbf{5}$ & Tannin & - & + & + & - & - & - & - & & - & + \\
\hline $\mathbf{6}$ & Flavonoid & - & - & + & - & + & + & + & + & + \\
\hline $\mathbf{7}$ & Alkaloids & + & + & + & + & + & + & + & + & + \\
\hline
\end{tabular}

\section{RESULTS AND DISCUSSION:}

In present study secondary metabolites such as cardiac glycosides, terpenoids, steroids, saponin, tannin flavonoid and alkaloids have screened in petroleum ether, chloroform and methanol extracts of root, leaves and seeds of Pinda concanensis and Heracleum grande.

Petroleum ether extracts in Pinda concanensis of roots and leafs reported with presence of terpenoids only but seed extracts showed presence of Glycosides, terpenoids, steroids and tannins.

While in $H$. grande roots and leaf extracts showed presence of glycosides, terpenoids, saponins and alkaloids and seeds extracts additionally showed presence of flavonoids also.

As compare to Petroleum ether extracts, Chloroform extracts showed presence of more types of compounds. In case of Pinda concanensis root, leaf and seeds extracts reported with presence of terpenoids, steroids and tannins only seeds extracts with additional presence of glycosides.

$H$. grande chloroform extracts of roots showed presence of Glycosides, terpenoids, saponins, tannins and alkaloids. Leaf extracts showed presence Glycosides, steroids, flavonoids and alkaloids while chloroform seed extracts showed all phytochemicals except tannins.

In case of root and seed methanolic extracts of Pinda concanensis and methanolic seed extracts of $H$. grande showed presence of all tested phytochemicals viz. cardiac glycosides, terpenoids, steroids, saponin, tannin flavonoid and alkaloids. While leaf methanolic extracts of both plants showed absence of tannins. In case of roots methanolic extracts of $H$. grande showed absence of terpenoids and saponins.

Terpenoids were reported in all extracts of Pinda concanensis and Cardiac glycosides overall reported in H. grande.

Above results depict that methanolic extracts were rich in all most all types of metabolites while petroleum ether extracts showed less variety of compounds.

\section{CONCLUSION:}

Phytochemical screenings of chemical constituents are important for discovery of novel drugs for pharmaceutical industries as well as for cosmetic industries also ${ }^{6}$. In present study it was reflected that, both plants having presence of wide range of secondary metabolites, which were proved good to understand importance of phytochemicals and there is scope for identification bioactive compounds.
There were several reports on phytochemical screening of members of family Apiaceae ${ }^{1}$. The phytochemical investigation reported presence of glycosides, terpenoids, tannins, flavonoids, saponins, steroids and alkaloids from both plants. This phytochemical screening may be helpful in the investigation of novel bioactive compounds subsequently it may be helpful for development of new plant based pharmaceuticals which can be good alternative to synthetic medicines $^{9,10}$. These biologically active compounds can be potentially used for advancement in herbal pesticides, insecticides etc. for progress in organic farming.

\section{REFERENCES:}

1. Sood K., Yadav RNS., Phytochemical Screening and Antimicrobial Activity of four members of Family Apiaceae. International journal of phytomedicine 2014; 6(2):232-236.

2. Dubey N. K. Kumar R., and Tripathi, P., Global Promotion of herbal medicine; India's opportunity. Curr. Med. (2004); 86:37-41.

3. Okoh AL, Ncube NS and Afolayan A. Assessment techniques of antimicrobial properties of natural compounds of plant origin. African J Biotechnology 2008; 7(12):1797-1808. https://doi.org/10.5897/AJB07.613

4. Downie S R, Katz-Downie D S, Watson M F. A phylogeny of the flowering plant family Apiaceae based on chloroplast DNA rpl16 and rpoC1 intron sequences: towards a suprageneric classification of subfamily Apioideae. Am J Bot 2000; 87:273-92. https://doi.org/10.2307/2656915

5. Ebeed, N.M., Abdou, H.S., Booles, H.F., Salah, S.H., Ahmed, E.S., Fahmy, K.H.,Antimutagenic and chemoprevention potentialities of sweet fennel (Foeniculum vulgare mill.) hot water crude extract.J. Am. Sci. 2010; 6:831-842.

6. Sharma V. and Pliwal R. Preliminary phytochemical investigation and thin layer chromatography profiling of sequential extracts of Moringa oleifera pods International Journal of Green pharmacy 2013; 41-45. https://doi.org/10.4103/0973-8258.111607

7. Stansbury J. The Apiaceae family medicinal plant research summary Mar 2016.

8. Bidve S.C. and Auti S.G. A Comparative Analysis of Effect of Solvent And Extraction Technique on Recovery of Bioactive Compounds From Different Plant Parts of Pinda Concanensis Plant Archives 2020; 21(1):910-914.

9. Al-Mansur M.A., Siddiqi M.M.A., Akbor M.A., and Saha K Phytochemical Screening and GC-MS chemical profiling of Ethyl Acetate Extracts of Seed and Stem of Anethum sowa Linn. Dhaka Uni. J. Pharm.Sci. 2017; 16(2):187-194. https://doi.org/10.3329/dujps.v16i2.35256

10. Dubey N. K. Kumar R., and Tripathi, P., Global Promotion of herbal medicine; India's opportunity. Curr. Med. 2004; 86:37-41. 
11. Dusko B.L., Comic L., Solujic-Sukdolak S. Antibacterial activity of some plants from family apiaceae in relation to selected phytopathogenic bacteria Kragujevac J. Sci. 2006; 28:65-72.

12. Ebadollahi A. Plant Essential Oils from Apiaceae Family as Alternatives to Conventional Insecticides Ecologia balkanica 2013; 5(1):149-172.

13. Evergetis E., Michaelakis A., Kioulos E., Koliopoulos G., Haroutounian S.A. Chemical composition and larvicidal activity of essential oils from six Apiaceae family taxa against the West Nile virus vector Culex pipiens. Parasitology Research, 2009; 105:117-124. https://doi.org/10.1007/s00436-009-1370-8

14. Shrivastava D.K. Phytochemical Analysis of a Miracle herb Coriander sativum Indian J. Sci. Res. 2017; 13(2):09-14.

15. Tadesse S., Ganesan K., Nair S.K.P., Letha N. and Gani S.B.preliminary phytochemical investigation of different solvent extracts of Centella asiatical. (family: apiaceae), an ethiopian weed IJPCBS 2016; 6(1):97-102.

16. Tine Y., Renucci F., Costa J, Wele A and Paolini J. Method for LCMS/MS Profiling of Coumarins in Zanthoxylum zanthoxyloides (Lam.) B. Zepernich and Timler Extracts and Essential Oils Molecules 2017; 22:174.

https://doi.org/10.3390/molecules22010174

17. Upadhyay R. K., J. Gayatri, Y Neeraj. Tocixity, repellency and oviposition inhibitory activty of some essential oils against Callosobruchus chinensis. Journal of Applied Bioscience, 2007; 33(1):21-26.

18. Wink M. Modes of Action of Herbal Medicines and Plant Secondary Metabolites Medicines 2015; 2:251-286. https://doi.org/10.3390/medicines2030251 